\section{The first decade of sibutramine and orlistat: a reappraisal of their expanding roles in the treatment of obesity and associated conditions}

\author{
A primeira década da sibutramina e do orlistate: reavaliação do seu \\ crescente papel no tratamento da obesidade e condições associadas
}

Walmir Coutinho'

\begin{abstract}
Ancillary therapies for weight management, consisting mainly of diet and exercise programs that incorporate variable levels of lifestyle modification techniques, are frequently ineffective to achieve clinically meaningful weight loss and maintenance. Although pharmacological treatment of obesity is widely used in most countries, the number of available drugs is still very limited. The most widely used anti-obesity agents are sibutramine and orlistat, both available in clinical practice for about a decade. A large number of clinical trials have demonstrated that both agents are safe and well tolerated, with a level of efficacy in the moderate weight loss recommended by the most relevant clinical guidelines. Several studies have assessed the efficacy and safety of sibutramine and orlistat in adolescents and also for the treatment of some associated conditions in adults, including type 2 diabetes, polycystic ovary syndrome and binge eating disorder. The positive results of these studies suggest an expanding role for both agents, not only for the treatment of obesity, but also for associated conditions. After the efficacy of orlistat for the prevention of type 2 diabetes demonstrated in the XENDOS study, the results of SCOUT study are awaited for a better evaluation of sibutramine impact on cardiovascular outcomes. Arq Bras Endocrinol Metab. 2009;53(2):262-270.
\end{abstract}

Keywords

Obesity; pharmacological treatment; sibutramine; orlistat; safety; efficacy; weight loss.

\section{RESUMO}

A terapia anciã para controle do peso, que consiste principalmente em programas de dieta e exercício incorporando técnicas de mudança de estilo de vida de diversos níveis distintos, é frequentemente ineficaz em atingir uma perda e manutenção de peso clinicamente significativas. Apesar de amplamente utilizado na maioria dos países o tratamento farmacológico da obesidade, o número de medicamentos disponíveis ainda é muito limitado. Os agentes antiobesidade mais utilizados são a sibutramina e o orlistate, ambos disponíveis na prática clínica há cerca de uma década. Em um grande número de ensaios clínicos já se demonstrou que ambos agentes são seguros e bem tolerados, com um nível de eficácia consistente de perda de peso moderada que se recomenda nas principais diretrizes clínicas. Vários estudos avaliaram a eficácia e segurança da sibutramina e do orlistate em adolescentes e também para o tratamento de algumas condições associadas em adultos, incluindo o diabetes tipo 2, a síndrome dos ovários policísticos e o transtorno da compulsão alimentar periódica. Os resultados positivos desses estudos sugerem que o papel dos dois medicamentos deverá ser expandido não apenas para o tratamento de um maior número de pacientes obesos, mas também para o tratamento de condições associadas. Depois que o orlistate teve sua eficácia demonstrada na prevenção do diabetes tipo 2 por meio do estudo XENDOS, os resultados do SCOUT são aguardados para uma melhor avaliação do impacto da sibutramina sobre os desfechos cardiovasculares. Arq Bras Endocrinol Metab. 2009;53(2):262-270.

Descritores

Obesidade; tratamento farmacológico; sibutramina; orlistate; segurança; eficácia; perda de peso. 


\section{INTRODUÇÃO}

$\mathrm{O}$ besity in humans results from the interaction of environmental factors with several genes with predisposition to weight gain. As a consequence of drastic environmental changes leading to overeating and sedentary behavior, obesity has reached epidemic proportions over the last few decades, also affecting developing countries, with severe implications on healthcare costs (1-3).

Obesity is currently defined as a body mass index (BMI) of $30 \mathrm{~kg} / \mathrm{m}^{2}$ or greater, considering overweight those individuals with a BMI between $25 \mathrm{~kg} / \mathrm{m}^{2}$ and $29.9 \mathrm{~kg} / \mathrm{m}^{2}$. There is still some discussion, however, about the appropriate "cut-off points" for BMI, especially in Asian population, for whom lower thresholds have been suggested (4).

According to a national survey in the United States (5), about $40 \%$ of women and $25 \%$ of men reported that they were currently trying to lose weight. However, most attempts are unsuccessful either because of failure to achieve significant weight loss or because of weight regain $(6)$.

Type 2 diabetes, hypertension, dislipidemia, osteoarthritis, and sleep apnea are tightly related to obesity (7-9), which is also an independent risk factor for heart disease (8).

Modest weight loss, in the range of $5 \%$ to $10 \%$, can result in marked reductions in the risk of several chronic diseases and metabolic complications of obesity (9).

\section{THE MEDICAL MANAGEMENT OF OBESITY}

The lifestyle modification program is the basis of obesity management (10). It has been demonstrated that the efficacy of pharmacological agents are directly related to the intensiveness of the lifestyle program (11). A comprehensive weight management program should include a structured physical activity planning, behavior modification, psychological support, medical management of associated conditions and long-term follow-up. The use of pharmacological agents as adjunctive therapy for weight management is universally recommended by the most relevant clinical guidelines and consensus documents $(12,13)$, whenever the patient has a BMI greater than $30 \mathrm{~kg} / \mathrm{m}^{2}$ and fails to achieve significant weight loss with diet and exercise alone. In the presence of associated conditions, such as type 2 diabetes, hypertension and dislipidemia the cut-off point for the pharmacological treatment recommendation is lowered to 27 or $25 \mathrm{~kg} / \mathrm{m}^{2}(12,13)$.

The currently available drugs for the treatment of obesity can be divided into three different categories.

Lipase inhibitor (orlistat), combined serotonergic and adrenergic agonist (sibutramine) and adrenergic agonists (diethylpropion, phentermine, mazindol and fenproporex $)(12,13)$. Other drugs have also been evaluated in weight management trials, although not considered anti-obesity agents and not officially approved for this indication, include fluoxetine, sertraline, topiramate and zonizamide (14).

\section{SIBUTRAMINE}

Sibutramine is a combined norepinephrine and serotonin reuptake inhibitor (Figure 1). The mode of action of sibutramine is mainly attributable to enhancement of satiety and decrease in caloric intake. Unlike anorectic drugs, the main effect of sibutramine on regulation of food intake appears to be closely related to enhancement of satiety rather than a direct effect of hunger suppression (15-17). Taken into consideration this distinctive pharmacological feature, sibutramine should be more adequately classified as a satiety agent instead of anorectic agent.

Although sibutramine has shown marked thermogenic properties in animals, studies in human failed to demonstrate a significant increase in energy expenditure, suggesting a partial prevention of the expected decrease in basal metabolic after weight loss $(18,19)$.

Sibutramine was approved in 1998 and has been widely evaluated in several trials (20-22). Among the trials ranging from 16 to 52 weeks, weight loss varied from 3.4 to $6.0 \mathrm{~kg}$ compared with placebo (21).

Systolic and diastolic blood pressure outcomes varied from small decreases to small increases. Fasting blood glucose level and hemoglobin Alc level decreased in sibutramine-treated patients. Small increases were reported for heart rate with an average of about 4 beats per minute.

An average of $4.5 \mathrm{~kg}$ more weight was lost at one year in the sibutramine group, and patients taking sibutramine had a $20 \%$ to $30 \%$ greater likelihood of losing at least $5 \%$ of their body weight than the patients receiving placebo (2l) (Figure 2).

Probably the most significant trial to evaluate the efficacy of sibutramine was designed as a weight maintenance study (22). After a single-blind phase during 

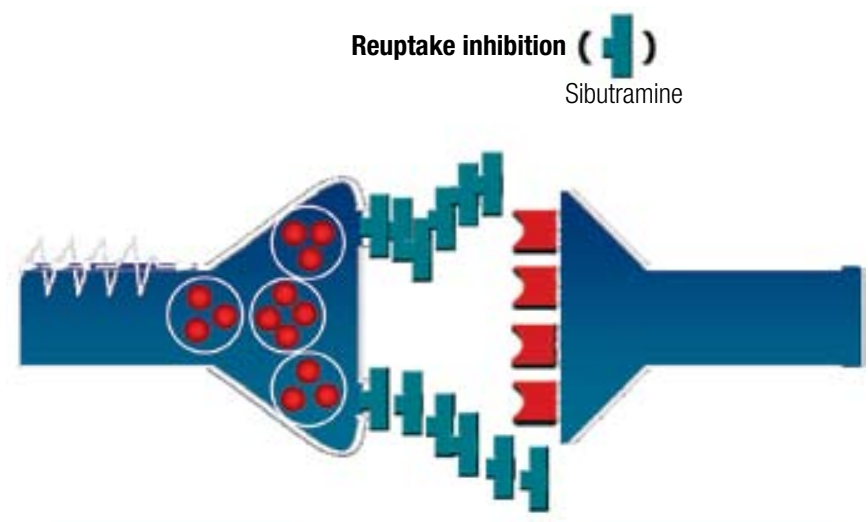

Monoamine

Receptor

Figure 1. Sibutramine: mechanism of action.

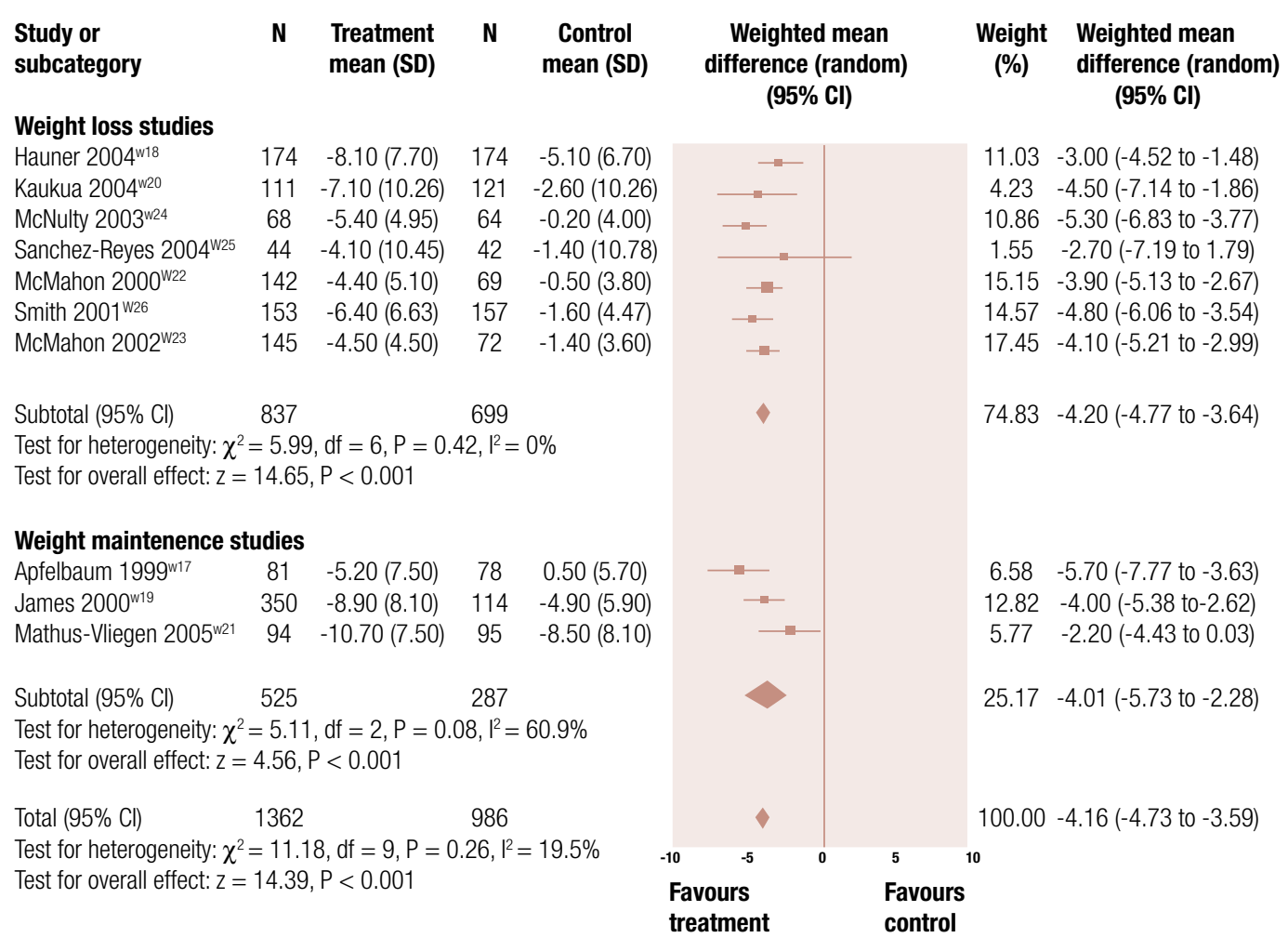

Figure 2. Placebo subtracted weight reduction $(\mathrm{kg})$ with sibutramine.

Source: Rucker and cols. (59).

which all patients received sibutramine, participants were randomized to either sibutramine 10 to $20 \mathrm{mg}$ or placebo. The Sibutramine Trial of Obesity Reduction and Maintenance study (STORM) demonstrated a higher maintenance of weight loss in sibutramine-treated obese patients in comparison to placebo (22).

\section{$-$}

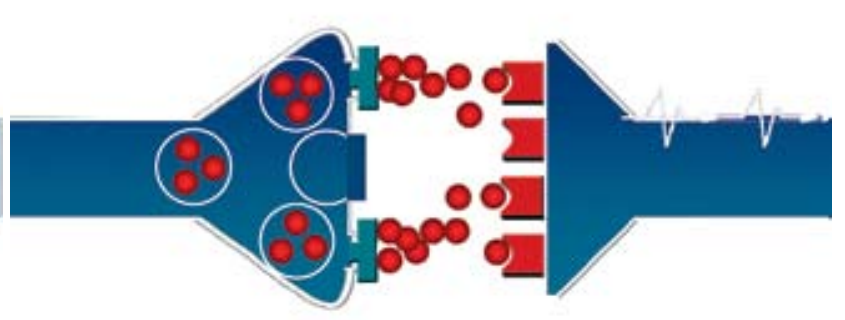

Monoamine
Other studies evaluated the efficacy of sibutramine in selective sub-groups of obese patients. Among adolescents, several small sample studies suggested that sibutramine could be well tolerated and safe, leading to a significant decrease in BMI (23-25). A large, multicentered randomised trial from the Sibutramine Ado- 
lescent Study Group (25), including 368 adolescent treated with sibutramine uptitrated to $15 \mathrm{mg}$ during one year, confirmed a statistically significant decrease in BMI and weight in the sibutramine group versus placebo. Concerning adverse events, only small, and yet statistically significant, differences in blood pressure and heart rate were described, similarly to what was previously reported in adults (25). From the evidence emerging from these studies, sibutramine could become, in the near future, a valid therapeutic option for obese adolescents, taken into account the need to monitoring blood pressure and pulse rate.

Efficacy of sibutramine on binge eating disorder has been also evaluated in controlled clinical trials. Positive results were demonstrated on predefined outcomes: decrease in body weight, decrease in binge eating episodes and decrease in psychiatric symptoms (26-28).

Although some concerns have been raised about the slight increase in blood pressure and pulse rate reported with sibutramine (28), post-marketing studies and the first reports from the Sibutramine

Cardiovascular Outcomes Trial (SCOUT) suggests that previously hypertensive patients tend to have a decrease in blood pressure when treated with sibutramine, despite a small increase in pulse rate $(29,30)$. The suggested mechanistic explanation is related to the central alphaadrenergic (clonidine-like) effect of sibutramine (31).

Preliminary reports from the SCOUT trial indicate that the overall safety and tolerability profiles appears to be similar to what was previously described for lower risk patients $(32,33)$.

Interestingly, the gender balance of the study population allowed us to compare the results for the six weeks lead-in period, with similar decreases in both weight and waist circumference reported for both genders (34).

\section{ORLISTAT}

Orlistat is currently the only lipase inhibitor approved for weight loss and a potent inhibitor of pancreatic and gastric lipases, acting locally in the gut lumen with minimal absorption (Figure 3). Orlistat inhibits dietary triglycerides hydrolysis by $30 \%$, decreasing proportionally fat absorption.

A mean placebo-subtracted weight loss of 2.8 to $3.2 \mathrm{~kg}$ was described in some meta-analysis, as well as significant improvement in blood pressure, lipids profile and metabolic control of type 2 diabetes (35-36) (Figure 4).
Some beneficial metabolic impacts of orlistat seem to be independent of weight loss. The observed reduction in triglycerides and low-density lipoprotein (LDL) cholesterol levels on orlistat-treated patients is more than $10 \%$ higher than the expected for the weight loss per se. The mechanistic explanation is based on the $25 \%$ reduction on the intestinal cholesterol absorption elicited by orlistat (37).

Moreover, the reduction in lipid absorption has been related to a decrease in the intra-abdominal fat content, $44 \%$ over the observed with a comparable weight reduction induced by diet alone (38). The largest placebo-controlled study performed with orlistat was the XENDOS (XENical in the Prevention of Diabetes in Obese Subjects), that aimed at assess orlistat efficacy in preventing type 2 diabetes in obese patients (39). A total of 3305 obese patients were randomised to intensive lifestyle modification program plus orlistat or placebo for a period of four years. The cumulative incidence of diabetes was significantly reduced by $37.3 \%$. Furthermore, treatment with orlistat was also associated with sustained improvements of several other cardiovascular risk factors, including blood pressure, waist circumference and lipids (39).

Other studies involving smaller number of patients have also demonstrated several features of amelioration in metabolic and endocrine profile, mostly secondary to weight loss itself, including the reduction in alfa-tumor necrosis factor, interleukin-6, postprandial lipaemia and atherogenic lipoproteins. An increase in adiponectin levels was also reported, as well as the amelioration of hepatic steatosis (40-42).

Although patients with type 2 diabetes lose less weight with orlistat than non-diabetic patients, they have significant reductions in fasting glucose and glycosylated haemoglobin (HbAlc) (43). The impact on glycemic control is greater than expected for the degree of weight loss. In a retrospective analysis of pooled data from seven multicentre, double-blind, placebo-controlled studies involving overweight or obese patients with type 2 diabetes, orlistat provided significant larger mean decreases in HbAlc compared with placebo (43). For patients with minimal or no weight loss (less than $1 \%$ of baseline body weight), orlistat $120 \mathrm{mg}$ still provided a significantly greater decrease in the least squares mean value for both fasting plasma glucose (FPG) and HbAlc. It suggested that the improvement of glycemic control with orlistat $120 \mathrm{mg}$ was independent of weight loss. Using linear regression analysis, improve- 
Fat digestion

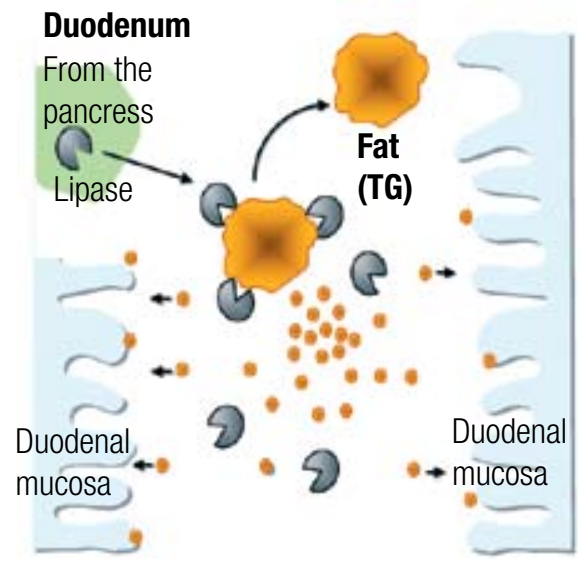

Orlistat - Mechanism of action

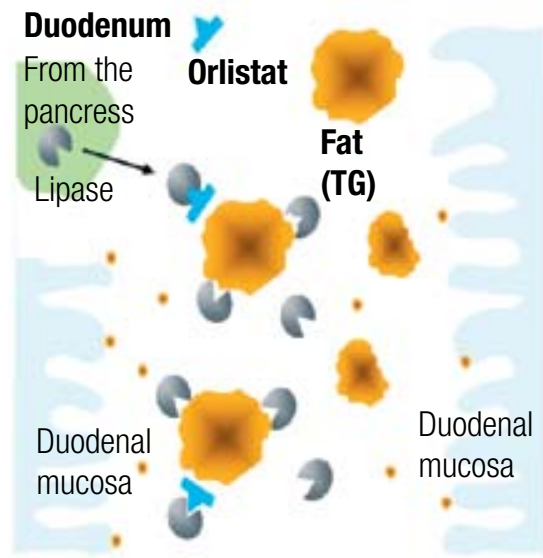

Figure 3. Orlistat - mechanism of action.

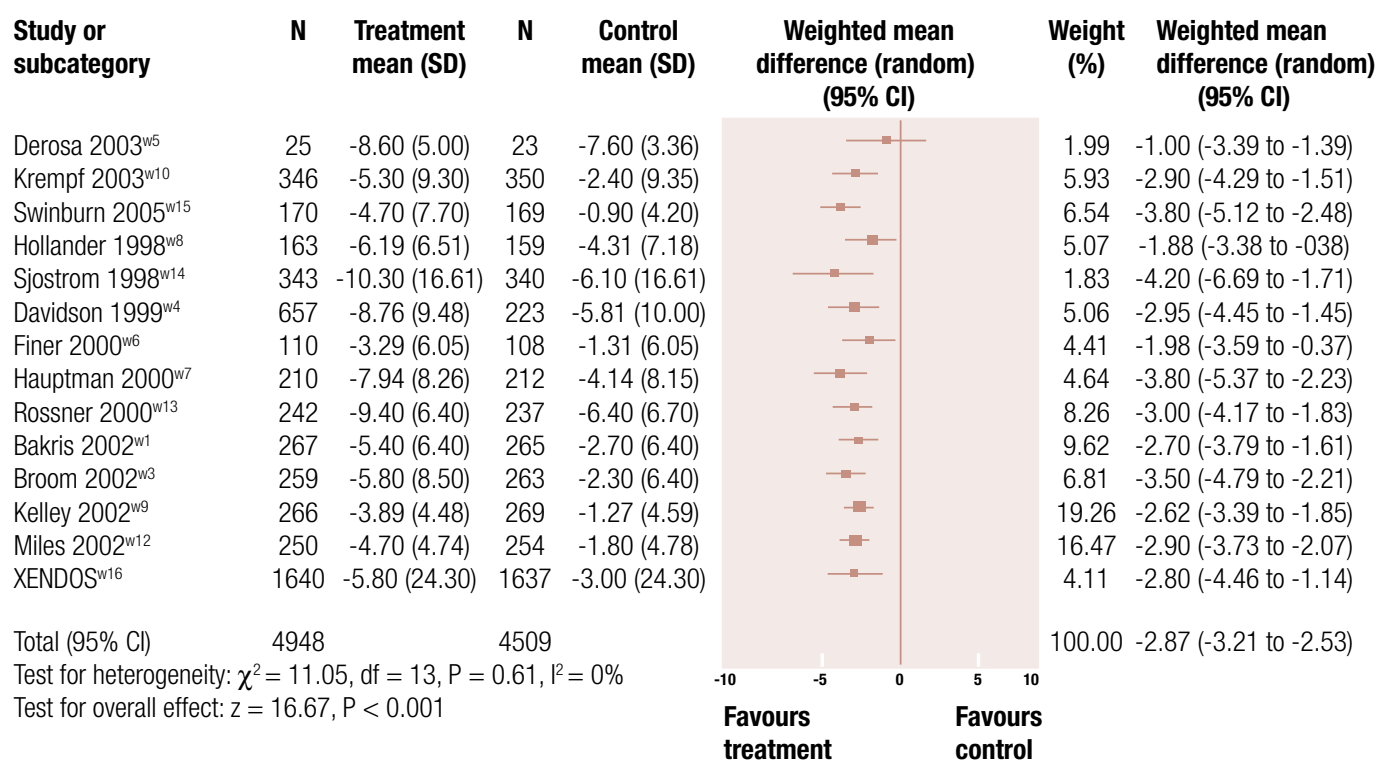

Figure 4. Placebo subtracted weight reduction (kg) with orlistat.

Source: Rucker and cols (59).

ment in glycemic control (FPG and HbAlc) with orlistat $120 \mathrm{mg}$ was less strongly correlated with weight loss than for placebo. The postulated mechanisms underlying this effect include an improvement of insulin sensitivity, a slower and incomplete digestion of dietary fat, a reduction of postprandial plasma non-esterified fatty acids, a decreased visceral adipose tissue and the stimulation of glucagon-like peptide- 1 secretion in the lower small intestine (43-45).

Like sibutramine, orlistat has been tested for selected subpopulations of obese patients, such as adoles- cents $(46,47)$ and patients with specific associated conditions, including binge eating disorder (BED) $(48,49)$ and polycystic ovary syndrome (PCOS) $(50,51)$.

For the treatment of obese adolescents, orlistat was shown to be safe, well tolerable and effective $(46,47)$. Orlistat is currently approved by the FDA for the treatment of adolescents from 12 to 16 years old.

Binge eating disorder, a psychiatric condition highly prevalent among obese patients seeking medical treatment for weight loss, was also improved in two placebo-controlled clinical trials $(48,49)$. Despite the 
lack of demonstrated central nervous system activity, orlistat was more effective than placebo in controlling binge eating. Intent-to-treat remission rates were significantly higher for orlistat $(64 \%$ versus $36 \%$ in the placebo group) at post treatment but not at three-month follow-up (52\% in both). Also intent-to-treat rates for achieving $5 \%$ weight loss were significantly higher for orlistat (36\% versus $8 \%$ ). With regard to eating disorder psychopathology and psychological distress, significant and comparable improvements occurred in both treatments (orlistat not different from placebo) (49).

In the treatment of obese women with PCOS, testosterone levels had a significant decrease attributed to the first trimester, whereas testosterone levels did not change during the second 12 -week period. In women with PCOS, insulin levels and HOMA-IR values were decreased during the first 12 weeks, whereas no significant change was observed during the second trimester $(50,51)$.

\section{COMBINATION THERAPY OF SIBUTRAMINE WITH ORLISTAT}

In some studies, sibutramine and orlistat have been used in combination (52-55).

In the first trial to assess the efficacy of this combination, the patients were only randomized to added orlistat or placebo after a previous weight loss period with sibutramine alone. The participants had lost an average of $11.6 \pm 9.2 \%$ of initial weight during the prior first year of treatment by sibutramine combined with lifestyle modification. The addition of orlistat to sibutramine did not induce further weight loss as compared with treatment by sibutramine alone (52). In another study (53), the patients were randomly divided into three therapy groups: diet plus orlistat, diet plus sibutramine and diet plus combination of orlistat and sibutramine. The amount of weight loss reported for the three groups did not demonstrate any advantage of the combination therapy comparing to sibutramine alone.

A randomized open-label short term trial (54) evaluated the impact of four different regimens on BMI. A total of 86 patients were treated for a 12 weeks period after randomization to one of four different groups: sibutramine $10 \mathrm{mg}$, orlistat $3 \times 120 \mathrm{mg}$, combination therapy with orlistat + sibutramine, or diet alone. The decreases in BMI were: sibutramine: $-4.41 \pm 1.26 \mathrm{~kg} /$ $\mathrm{m}^{2}$; orlistat $-3.64 \pm 0.97 \mathrm{~kg} / \mathrm{m}^{2}$; sibutramine+orlistat $-5.12 \pm 1.44 \mathrm{~kg} / \mathrm{m}^{2}$ and diet alone $-2.52 \pm 1.36 \mathrm{~kg} /$ $\mathrm{m}^{2}$. Decreases in BMI did not statistically differed be- tween the sibutramine group and the combination therapy group (54).

Interestingly, the authors reported in another publication differences between groups concerning variation in fat distribution (55). Although sibutramine monotherapy was significantly more effective in inducing BMI decrease compared to orlistat mono-therapy, the association between change in BMI and change in waist circumference was strongest in the orlistat mono-therapy group ( $\mathrm{p}=0.003)$, suggesting that patients taking orlistat had more decrease in waist circumference per unit decrease in BMI compared to patients under combination therapy and patients taking sibutramine (55). Given the small sample size of the study and the limitation of indirect assessment of visceral fat by measuring waist circumference, the finds should be interpreted with caution.

\section{COST EFFECTIVENESS OF SIBUTRAMINE AND ORLISTAT}

Several studies assessed the cost-effectiveness of sibutramine and orlistat in the treatment of obesity and associated diseases. These studies have been evaluated in systematic reviews $(56,57)$, indicating that both orlistat and sibutramine appear to be beneficial for the treatment of adults with obesity (56).

In a more recent systematic review (57), nine articles were identified for orlistat and four for sibutramine. All used diet and exercise as comparator, whereas none included indirect costs. Time horizons varied from treatment period only ( $1-4$ years) to 80 years (median 7.5 years). Longer studies modeled effects on diabetes, micro- and macrovascular complications, coronary heart disease and death. The worst cost-effectiveness results were obtained when recommended stop rules for nonresponding patients were not applied. The authors concluded that published economic evaluations indicate that orlistat and sibutramine are within the range of what is generally regarded as cost-effective (57).

\section{DISCUSSION}

One of the main challenges for the management of the obese patient in daily clinical practice is to reconcile the patient's excessive expectation regarding weight loss with the amount of weight loss that can be actually achievable with the currently available pharmacological agents. While an obese woman usually wishes to lose more than 30 percent of her baseline weight, the aver- 
age amount of weight loss achieved is usually in the range of 5 to $10 \%(58,59)$.

Nevertheless, it has been well demonstrated that modest degrees of weight reduction, within the range of $5 \%$ to $10 \%$ of baseline body weight can translate into significant improvement of most obesity-related comorbidities. The average weight loss obtained with orlistat or sibutramine is consistent with the requirements of a clinically meaningful overall improvement of metabolic complications. In fact, most studies evaluating surrogate endpoints of cardiovascular risk have reiterated this notion (19-22;35-39).

Besides the metabolic benefits secondary to weight loss, both sibutramine and orlistat had direct metabolic benefits demonstrated, partially independent of weight loss. In the case of orlistat, the main weight-independent benefits seem to be on diabetes control (43) and LDL cholesterol reduction (37). As for sibutramine, there seems to be a decrease in blood pressure in previously hypertensive patients $(30)$ and a robust increase in HDL cholesterol levels $(23,24)$.

With the increasing prevalence of obesity among adolescents ( 1 ), there is a great need for new pharmacological options for the treatment of obese adolescents. While orlistat is already approved for adolescents in some countries, sibutramine could possibly be also recommended, for the evidence accumulated with published studies (23-25).

Regarding the treatment of associated diseases and conditions, it seems likely that both sibutramine and orlistat should be more widely used in overweight and obese patients with type 2 diabetes. In the case of orlistat, one could argue that, considering the weightindependent effect on blood glucose and hemoglobin Alc levels (43), the drug could be used for diabetic patients, even in the absence of weight loss.

Other associated conditions, including binge eating disorder, polycystic ovary syndrome and hepatic steatosis, might also be better controlled with the use of sibutramine and orlistat (26-28; 48-51).

Considering the limited efficacy of all anti-obesity agents, the same principle of add-on therapy widely applied to other chronic diseases, like type 2 diabetes and hypertension, it seems necessary to develop strategies for combining different drugs for weight loss. Given the different mechanisms of action of orlistat and sibutramine, it seems plausible to better assess the possibility of combining the two drugs. The main barrier is the lack of evidence that by combining sibutramine to orlistat, the amount of weight lost would be significantly increased. Unfortunately, the few studies available had important methodological limitations and failed to provide evidence that support the combination (52-55).

Taking into account that both sibutramine and orlistat are deemed cost-effective for the treatment of obese patients $(56,57)$, we should expect for the next years that these drugs will be used to treat a much larger number of patients, hopefully within the recommendations of our main guidelines and consensus documents. It seems also logical that these documents are accordingly updated, to incorporate the new evidence emerging from new studies.

Regardless of the mounting evidence that weight loss translates into amelioration of obesity-related diseases and surrogate markers of cardiovascular risk, an important question remains unanswered - can a weight loss program, pharmacological supported by an antiobesity agent reduce the risk of hard cardiovascular outcomes? It is expected for the near future that SCOUT, a double blind trial comparing sibutramine to placebo, might provide an answer.

Disclosure: Doctor Coutinho reports receiving a lecture fee from Sanofi-Aventis, Abbott, Roche, Novartis, Medley, Aché and Glenmark; serving as a consultant to Abbott, Medley, Roche, Johnson \& Johnson, Merck; and receiving research grants from Abbott, Roche, Johnson \& Johnson and Merck. No other potential conflict of interest relevant to this article was reported.

\section{REFERENCES}

1. WHO. Obesity: preventing and managing the global epidemic. Report of a WHO consultation. Technical Report Series. Geneva: World Health Organization; 2000. Report NN 894.

2. Friedrich MJ. Epidemic of obesity expands its spread to developing countries. JAMA. 2002;287(11):1382-6.

3. Sichieri R, Nascimento $S$, Coutinho W. The burden of hospitalization due to overweight and obesity in Brazil. Cad Saude Publica. 2007;23(7):1721-7.

4. WHO Expert Consultation. Appropriate body-mass index for Asian populations and its implications for policy and intervention strategies. Lancet. 2004;363(9403):157-63.

5. Williamson DF, Serdula MK, Anda RF, Levy A, ByersT. Weight loss attempts in adults: goals, duration, and rate of weight loss. Am J Public Health. 1992;82(9):1251-7.

6. Jeffery RW, Kelly KM, Rothman AJ, Sherwood NE, Boutelle KN. The weight loss experience: a descriptive analysis. Ann Behav Med. 2004;27(2):100-6.

7. National Task Force on the Prevention and Treatment of Obesity. Overweight, obesity, and health risk. Arch Intern Med. 2000;160(7):898-904.

8. Eckel RH, Krauss RM. American Heart Association call to action: obesity as a major risk factor for coronary heart disease. AHA Nutrition Committee. Circulation.1998;97(21):2099-100. 
9. Goldstein DJ. Beneficial health effects of modest weight loss. Int J Obes Relat Metab Disord. 1992;16(6):397-415.

10. Wadden TA, Berkowitz RI, Sarwer DB, Prus-Wisniewski R, Steinberg $\mathrm{C}$. Benefits of lifestyle modification in the pharmacologic treatment of obesity: a randomized trial. Arch Intern Med. 2001;161(2):218-27.

11. Thomas A, Wadden TA, Berkowitz RI, Womble LG, Sarwer DB, Phelan $S$ et al. RandomizedTrial of Lifestyle Modification and Pharmacotherapy for Obesity. N Engl J Med. 2005;353(20):2111-20.

12. Clinical Guidelines on the Identification, Evaluation, and Treatment of Overweight and Obesity in Adults: The Evidence Report. National Institute of Health. Obes Res. 1998;6 Suppl 2:51S-209S.

13. Coutinho WF, Cabral MD. A farmacoterapia da obesidade nos consensos. Arq Bras Endocrinol Metab. 2000;44(1):91-4.

14. Caterson ID. Medical Management of Obesity and its Complications. Ann Acad Med Singapore. 2009;38(1):22-7.

15. Mitchell JE, Gosnell BA, Roerig JL, de Zwaan M, Wonderlich SA, Crosby RD, et al. Effects of sibutramine on binge eating, hunger, and fullness in a laboratory human feeding paradigm. Obes Res. 2003;11(5):599-602.

16. Corrêa LL, Platt MW, Carraro L, Moreira RO, Faria Júnior R, Godoy-Matos AF, et al. [Evaluation of the sibutramine effect on satiety with a visual analogue scale in obese adolescents]. Arq Bras Endocrinol Metabol. 2005;49(2):286-90.

17. Hansen DL, Toubro S, Stock MJ, Macdonald IA, Astrup A. The effect of sibutramine on energy expenditure and appetite during chronic treatment without dietary restriction. Int J Obes Relat Metab Disord. 1999;23(10):1016-24.

18. Liu YL, Connoley IP, Harrison J, Heal DJ, Stock MJ. Comparison of the thermogenic and hypophagic effects of sibutramine's metabolite 2 and other monoamine reuptake inhibitors. Eur J Pharmacol. 2002;452(1):49-56.

19. Hauner H, Meier M, Wendland G, Kurscheid T, Lauterback KW. Weight reduction by sibutramine in obese subjects in primary care medicine: the S.A.T. study [Abstract]. Int J Obes Relat Metab Disord. 2000;24:S100.

20. McNulty SJ, Ur E, Williams G. A randomized trial of sibutramine in the management of obese type 2 diabetic patients treated with metformin. Diabetes Care. 2003;26(1):125-31.

21. Li Z, Maglione M, Tu W, Mojica W, Arterburn D, Shugarman LR, et al. Meta-analysis: pharmacologic treatment of obesity. Ann Intern Med. 2005;142(7):532-46.

22. James WP, Astrup A, Finer N, Hilsted J, Kopelman P, Rossner S, et al. Effect of sibutramine on weight maintenance after weight loss: a randomised trial. STORM Study Group. SibutramineTrial of Obesity Reduction and Maintenance. Lancet. 2000;356(9248):2119-25.

23. Godoy-Matos A, Carraro L, Vieira A, Oliveira J, Guedes EP, Mattos $L$ et al. Treatment of obese adolescents with sibutramine: $a$ randomized, double-blind, controlled study. J Clin Endocrinol Metab. 2005;90(3):1460-5.

24. Berkowitz RL, Wadden TA, Tershakovec AM, Cronquist JL. Behavior therapy and sibutramine for the treatment of adolescent obesity. A randomized controlled trial. JAMA. 2003;289(14):1805-12.

25. Berkowitz RI, Fujikova K, Daniels SR, Hopping AG, Owen S, Perry $A C$, et al. Effects of sibutramine treatment in obese adolescents. A randomized trial. Ann Intern Med. 2006;145(2):81-90.

26. Appolinario JC, Bacaltchuk J, Sichieri R, Claudino AM, GodoyMatos A, Morgan C, et al. A randomized, double blind, placebocontrolled study of sibutramine in the treatment of binge-eating disorder. Arch Gen Psychiatry. 2003;60(11):1109-16.

27. Milano W, Petrella C, Casella A, Capasso A, Carrino S, Milano L. Use of sibutramine, an inhibitor of the reuptake of serotonin and noradrenaline, in the treatment of binge eating disorder: a placebo-controlled study. Adv Ther. 2005;22(1):25-31.
28. McMahon FG, Fujioka K, Singh BN, Mendel CM, Rowe E, Rolston $\mathrm{K}$, et al. Efficacy and safety of sibutramine in obese white and African American patients with hypertension: a 1-year, doubleblind, placebo-controlled, multicenter trial. Arch Intern Med. 2000;160(14):2185-91.

29. Jordan J, Scholze J, Matiba B, Wirth A, Hauner H, Sharma AM. Influence of sibutramine on blood pressure: evidence from placebo-controlled trials. Int J Obes. 2005;29:509-16.

30. Sharma AM, Caterson ID, Coutinho W, Finer N, van Gaal L, Maggioni AP et al. Blood pressure changes associated with sibutramine and weight management - an analysis of the 6-week leading period of the Sibutramine Cardiovascular Outcomes (SCOUT) Trial. Diabetes Obes Metab. 2009;11(3):239-50.

31. Birkenfeld A, Schroeder C, Boschman M, Tank J, Franke G, Luft $\mathrm{FC}$, et al. Paradoxical effect of sibutramine on autonomic cardiovascular regulation. Circulation. 2002;106(19):2459-65.

32. Torp-Pedersen C, Caterson I, Coutinho W, Finer N, Van Gaal L, Maggioni $A$, et al. Cardiovascular responses to weight management and sibutramine in high-risk subjects: an analysis from the SCOUT trial. Eur Heart J. 2007;28(23):2915-23.

33. Maggioni AP, Caterson I, Coutinho W, Finer N, Gaal LV, Sharma AM, Torp-Pedersen $C$, et al. Tolerability of sibutramine during a 6-week treatment period in high-risk patients with cardiovascular disease and/or diabetes: a preliminary analysis of the Sibutramine Cardiovascular Outcomes (SCOUT) Trial. J Cardiovasc Pharmacol. 2008;52(5):393-402.

34. Coutinho WF. The obese older female patient: CV risk and the SCOUT study. Int J Obes. 2007;31 Suppl 2:S26-32.

35. O'Meara S, Riemsma R, Shirran L, Mather L, ter Riet G. A systematic review of the clinical effectiveness of orlistat used for the management of obesity. Obes Rev. 2004;5(1):51-68.

36. Hutton B, Fergusson D. Changes in body weight and serum lipid profile in obese patients treated with orlistat in addition to a hypocaloric diet: a systematic review of randomized clinical trials. Am J Clin Nutr. 2004;80(6):1461-8.

37. Mittendorfer B, Ostlund RE, Patterson BW, Klein S. Orlistat inhibits dietary cholesterol absorption. Obes Res. 2001;9(10):599-604.

38. Tiikkainen M, Bergholm R, Rissanen A, Aro A, Salminen I,Tamminen $M$, et al. Effects of equal weight loss with orlistat and placebo on body fat and serum fatty acid composition and insulin resistance in obese women. Am J Clin Nutr. 2004;79(1):22-30.

39. Torgerson JS, Hauptman J, Boldrin MN, Sjostrom L. XENical in the Prevention of Diabetes in Obese Subjects (XENDOS) Study: a randomized study of orlistat as an adjunct to lifestyle changes for the prevention of type 2 diabetes in obese patients. Diabetes Care. 2004;27(1):155-61.

40. Sutera PM, Marmiera G, Veya-Linderb C, Hanselerc E, Lentzb J, Vettera W, et al. Effect of orlistat on postprandial lipemia, NMR lipoprotein subclass profiles and particle size. Atherosclerosis. 2005;180(1):127-35.

41. Zelber-Sagi S, Kessler A, Brazowsky E, Webb M, Lurie $Y$, Santo $M$, et al. A double-blind randomized placebocontrolled trial of orlistat for the treatment of nonalcoholic fatty liver disease. Clin Gastroenterol Hepatol. 2006;4(5):639-44.

42. Hsieh CJ, Wang PW, Liu RT, Tung SC, Chien WY, Chen JF, et al. Orlistat for obesity: benefits beyond weight loss. Diabetes Res Clin Pract. 2005;67(1):78-83.

43. Jacob S, Rabbia M, Meier MK, Hauptman J. Orlistat $120 \mathrm{mg}$ improves glycaemic control in type 2 diabetic patients with or without concurrent weight loss. Diabetes Obes Metab. 2009;11(4):361-371.

44. Kelley DE, Kuller LH, McKolanis TM, HarperT, Mancino J, Kalhan S. Orlistat on insulin resistance, regional adiposity, and fatty acids in type 2 diabetes mellitus. Diabetes Care. 2004;27(1):33-40. 
45. Damci T, Yalin S, Balci H, Osar Z, Korugan U, Ozyazer M, et al. Orlistat augments postprandial increases in glucagon-like peptide 1 in obese type 2 diabetic patients. Diabetes Care. 2004;27(5):1077-80.

46. McDuffie JR, Calis KA, Uwaifo GI, Sebring NG, Fallon EM, Hubbard VS, et al. Three month tolerability of orlistat in adolescents with obesity related comorbid conditions. Obes Res. 2002;10(7):642-50.

47. Chanoine JP, Hampl S, Jensen C, Boldrin M, Hauptman J. Effect of orlistat on weight and body composition in obese adolescents. a randomized controlled trial. JAMA. 2005;293(23):2873-83.

48. Golay A, Laurent-Jaccard A, Habicht F, Gachoud JP, Chabloz M, Kammer $A$, et al. Effect of orlistat in obese patients with binge eating disorder. Obes Res. 2005;13(10):1701-8.

49. Grilo CM, Masheb RM, Salant SL. Cognitive behavioral therapy guided self-help and orlistat for the treatment of binge eating disorder: a randomized, double-blind, placebo-controlled trial. Biol Psychiatry. 2005;57(10):1193-201.

50. Diamanti-Kandarakis E, Piperi C, Alexandraki K, Katsilambros N, Kouroupi E, Papailiou J, et al. Short-term effect of orlistat on dietary glycotoxins in healthy women and women with polycystic ovary syndrome. Metabolism. 2006;55(4):494-500.

51. Panidis D, Farmakiotis D, Rousso D, Kourtis A, Katsikis I, Krassas G. Obesity, weight loss, and the polycystic ovary syndrome: effect of treatment with diet and orlistat for 24 weeks on insulin resistance and androgen levels. Fertil Steril. 2008;89(4):899-906.

52. Wadden TA, Berkowitz RI, Womble LG, Sarwer DB, Arnold ME, Steinberg CM. Effects of sibutramine plus orlistat in obese women following 1 year of treatment by sibutramine alone: a placebocontrolled trial. Obes Res. 2000;8(6):431-7.
53. Sari R, Balci MK, Cakir M, Altunbas H, Karayalcin U. Comparison of efficacy of sibutramine or orlistat versus their combination in obese women. Endocr Res. 2004;30(2):159-67.

54. Kaya A, Aydin N, Topsever P, Filiz M, Oztark A, Daar A, et al. Efficacy of sibutramine, orlistat and combination therapy on shortterm weight management in obese patients. Biomed Pharmacother. 2004;58(10):582-7.

55. Aydin N, Topsever P, Kaya A, Karasakal M, Duman CA. Orlistat, sibutramine, or combination therapy: which performs better on waist circumference in relation with body mass index in obese patients? Tohoku J Exp Med. 2004;202(3):173-80.

56. Avenell A, Broom J, Brown TJ, Poobalan A, Aucott L, Stearns $\mathrm{SC}$, et al. Systematic review of the long-term effects and economic consequences of treatments for obesity and implications for health improvement. Health Technol Assess. 2004;8(21):iiiiv, 1-182.

57. Neovius M, Narbro K. Cost-effectiveness of pharmacological anti-obesity treatments: a systematic review. Int $\mathrm{J}$ Obes. 2008;32(12):1752-63.

58. Foster GD, Wadden TA, Vogt RA, Brewer G. What is a reasonable weight loss? Patients' expectations and evaluations of obesity treatment outcomes. J Consult Clin Psychol. 1997;65(1):79-85.

59. Rucker D, Padwal R, Li SK, Curioni C, Lau DC. Long term pharmacotherapy for obesity and overweight: updated meta-analysis. BMJ. 2007;335(7631):1194-9.

60. Filippatos TD, Kiortsis DN, Liberopoulos EN, Mikhailidis DP, Elisaf MS. A review of the metabolic effects of sibutramine. Curr Med Res Opin. 2005;21(3):457-68. 